\title{
Correction: Exploring why 'primary care' problems end up receiving ambulance treatment: early findings from a pre-hospital ethnographic study
}

Mathew Brooker, Rebecca Barnes, Alison Heawood, et al. Exploring why 'primary care' problems end up receiving ambulance treatment: early findings from a pre-hospital ethnographic study. Emerg Med J 2017;34:697. doi:10.1136/emermed-2017-207114.5.

The name of the first author, Matthew Booker, is misspelled in the author list. The correct list of authors is: Matthew Booker, Rebecca Barnes, Alison Heawood.

(c) Article author(s) (or their employer(s) unless otherwise stated in the text of the article) 2017. All rights reserved. No commercial use is permitted unless otherwise expressly granted.

Emerg Med J 2017;34:e13. doi:10.1136/emermed-2017-207114.5corr1

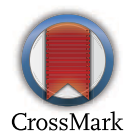

